\title{
IMPLEMENTATION AND IMPACT OF A HALAL FOOD STANDARD: AN EMPIRICAL STUDY OF MALAYSIA
}

\author{
Dian Permata Sari ${ }^{1}$, Irwandi Jaswir ${ }^{2}$ and Mohd. Radzi bin Haji Che Daud ${ }^{3}$ \\ ${ }^{1}$ International Institute of Halal Research and Training (INHART) \\ International Islamic University Malaysia (IIUM), Malaysia, dpsari72@gmail.com \\ ${ }^{2}$ INHART, IIUM, Malaysia, irwandi@iium.edu.my \\ ${ }^{3}$ Kuliyyah of Engineering, IIUM, Malaysia, mradzi@iium.edu.my
}

\begin{abstract}
As a Malaysian halal food standard, MS1500 was established to strengthen the Malaysian role in the global halal market. This study aims to identify the factors affecting the implementation of MS1500, its positive impact, and the relationship between its implementation and impact. The food and beverages industry in Malaysia, which already has a halal certificate and halal logo, was chosen as the study population. The covariance-based structural equation modelling (CB-SEM) method was employed, with 212 sample companies. The results show that Perception-On-Implementation, Halal-Control-System-Activity and Owner-Management-Employee-Limitation were the factors affecting the implementation of MS1500. Four positive impacts of its implementation were also found: Trade \& Free Movement, Innovation, Clean \& Save Production-Process and Consumer \& Corporate Image. In addition, it was discovered that the better the implementation of MS 1500, the greater the positive impact that could be achieved by the industry. It was also found that in Malaysia, finance and regulations were not the factors causing limitations in the implementation of the halal food standard. The findings of the study can be used as an input for Malaysian government in planning suitable programmes to promote the implementation of the standard. Moreover, the extent of the positive impacts of the implementation on the industry is expected to encourage all food sectors in Malaysia to apply and fully implement MS1500 in their daily operations.
\end{abstract}

Keywords: MS1500, Implementation, Positive-impact, Halal food industry. JEL classification: G41; L15; L66; P49.

Article history:

Received : October 5, 2020

Revised : February 22, 2021

Accepted : : May 27, 2021

Available online : August 31, 2021

https://doi.org/10.21098/jimf.v7i3.1302 


\section{INTRODUCTION}

\subsection{Background}

The Global Islamic Economic Report (2019) forecast that the size of the halal food industry market in 2023 would be around US\$ 1,863 billion. Such a high value could benefit several countries around the world, including Malaysia. Accordingly, the Malaysian government has chosen the halal industry as one of its strategic master plans, overall terming it the Halal Industry Master Plan (HIMP) 2006-2020 and HIMP 2020-2030. To strengthen its role in the global regulation of halal products, the Malaysian government has introduced Malaysia Halal Food Standard-MS1500.

To date, MS1500 is the only basic reference used by JAKIM (Jabatan Kemajuan Islam Malaysia) and the State Islamic Religious Council to issue certificates for halal food in Malaysia. The MS was launched in 2000 and was revised three times in 2004, 2009 and 2019. MS 1500 is the most popular halal MS and has been widely applied for the last decade. Therefore, it has been recognised by the United Nations as a benchmark for international halal standards (Bohari, Hin, \& Fuad, 2013).

The implementation of MS1500 is expected to have many positive impacts on all parties, including industries or business players, suppliers, customers, and the government. Accordingly, much hope was expressed by the Malaysian government that its implementation would be successful. However, the requirements involved are relatively complicated and include challenges that frequently lead to unsuccessful execution (Din \& Daud, 2014).

One of the factors that leads to the unsuccessful implementation of MS 1500 is the assumption by a relatively high number of SMEs that it is typically associated with high costs (Sunarya, Firdausy, Busneti, \& Adinugroho, 2015). Another issue relates the fact that there are food and beverage SMEs owned by indigenous Muslims in Malaysia who still take the word "halal" for granted. These SMEs claim that their products are halal, without ever signing up for the official halal certificate and implementing the halal standard.

Moreover, from the review of the related literature, it was found that studies of halal food certification and halal standards mainly focus on the consumer side rather than the industry side. Accordingly, it is important to conduct a holistic study on the implementation of MS1500, paying more attention to the industry side, especially the halal food industry.

\subsection{Objective}

The study aims to identify the factors affecting the implementation of MS1500. It also intends to identify the positive impact of its implementation on the halal food industry in Malaysia. Additionally, the aim is also to examine and analyse the relationship between the implementation of MS1500 and its positive impact.

This study consists of five sections. The background and objective are presented in Section I. Section II comprise several reviews of the background theory pertaining to all the variables, previous studies and conceptual framework. Section III concerns the methodology, with discussion of the data, model development, research analysis steps and method, while Section IV consists of a description of the results of each step of the analysis, which are presented in tables and figures, 
together with an in-depth analysis of the results. The final section (Section V) concludes the study and provides several recommendations.

\section{LITERATURE REVIEW}

\subsection{Background}

\subsubsection{Implementation of MS 1500 and Its Expected Impact}

According to the Department of Standards Malaysia (2009), Malaysian Standard (MS) is a consensus document developed by the Standards Development Committee (SDC) within the Malaysian Standards Development System. The standard was developed based on demand and market relevance, in accordance with the principles laid down by international standard setters such as the World Trade Organization (WTO) and the International Standard Organization (ISO). Before its official launch, an MS needs approval from the Minister of Science, Technology and Innovation.

As of 28 February 2018, out of. 5338 Malaysian standards developed, only 23 were Malaysian halal standards (15 in English and eight translated into Malay). According to Jabatan Agama Islam Selangor (2019), halal MSs are developed based on the requirements and needs of Malaysia as a country which has a Muslim population of around $60 \%$. Therefore, MS1500 was developed out of the necessity to have a specific standard that could cater for halal food in the country.

MS 1500 was launched in 2000 and first revised in 2004. The second revision was launched in 2009 and the latest in the first quarter of 2019. MS 1500 is focused on halal food, and is used by JAKIM as a basic reference in issuing halal certificates and halal logos. To date, MS 1500 has been the most popular halal MS in Malaysia.

The Malaysian government is eager to see the successful implementation of MS1500 as its leading product. The Department of Standards Malaysia (2009) has listed 16 expected benefits of implementing MS1500 for all stakeholders. In tandem with the DSM, Malaysian International Food and Beverages (MIFB) has stated three major economic benefits of the implementation of MS1500: (1) Increasing competitiveness in the global marketplace; (2) simplifying technical information exchange; and (3) helping avoid the cost of testing and recertification when moving into a new market.

\subsubsection{Theory of Implementation Science and Research}

Implementation science was defined by Padian, Holmes, McCoy, Lyerla, Bouey, \& Goosby (2011), as cited by Dunn et al. (2012), as the study of methods to improve the uptake, implementation, and translation of research findings into routine and common practices. Implementation is not an event, but a long process. Fixsen, Naoom, Blasé, Friedman, and Wallace (2005) defined it as a specified set of activities which is used in practice, activities, or programmes. Implementation can take place at different levels: practitioners, agencies, or communities.

Ideally, the results of successful implementation research should be able to benefit practitioners and policymakers. Good research should be able to provide lessons to practitioners about the best way to run effective programmes and to advise policymakers about how to improve existing interventions. Practitioners, 
should also be guided on the ways to optimally run effective programmes to improve current policies.

According to Peters, Tran, and Adam (2013), the important aspects of implementation research are the context or the factors affecting implementation; the implementation processes themselves; the limitations of or barriers to implementation; and the outcomes, end-products or impacts of the implementation under study. Moreover, Peters et al. (2013) state that elaborating respondents' understanding of the context of the implementation can be achieved by asking them about their perceptions of the matter in hand. In addition, understanding of the process of the implementation can be gained by asking about the core activities in the implementation itself. Additionally, Peters et al. (2013) explain that the desirable outcomes of an implementation are achieved only when all the barriers can be overcome.

\subsubsection{Standards: Their Implementation and Impact}

The International Organization for Standardization and the International Electrotechnical Commission have defined a standard as "a document which is produced by consensus and approved by a recognized body that provides for common and repeated use, rules, guidelines or characteristics for activities or their results, aimed at the achievement of the optimum degree of order in a given context" (ISO/ IEC Guide, 2004). Accordingly, Weitzel, Beimborn, and Konig (2006) conclude that standards play a prominent role in systems characterised by the interaction of several players. They can be used as a reference for any technology or product incorporating specifications that provide its compatibility. Giovannucci and Reardon (2001) defined standards as the parameters that categorise similar products and described them with understandable, consistent terminologies.

Standards are designed as the best way to ensure that a product is safe, to give assurance to customers, and to add value to products, services or processes. Talib and Ali (2009) explain that on one hand standards are essential tools for local and international businesses, which shape the contribution of economic progress through industry development and trade, as well as acting as guidelines in the assurance of consumer protection. On the other hand, they can eliminate trade barriers and facilitate the exchange of goods and services across borders.

\subsubsection{Implementation of Standards (Standardisation)}

Based on the user perspective adopted in their work, "standardisation" is defined by Weitzel, Beimborn, and Konig (2006) as the implementation of a standard to interact with a communication partner. Another definition of standardisation is "the process of formulating, drafting, publishing and reviewing appropriate technical standards for the benefit of individuals, businesses, governments and/ or society, together with implementing them through relevant Regulations, Testing and Certification, Marking and Labelling, Inspection and Surveillance" (Bellina et al., 2002). One of the main objectives of standardisation is to ensure everyone adheres to the same procedures or product specifications, which in return facilitates logistical procedures and trade, prevents consumer deception, and improves product quality (Dankers, 2003). 
With very few exceptions, the implementation of standards is voluntary (Jungmittag, Blind, \& Mangelsdorf, 2011; Jais, 2009). It is up to individuals or companies to decide whether they want to adopt them or not. A standard can be selected as mandatory when it has a direct effect on consumer safety, has an environmental impact, and/or poses health issues, so regulatory agencies can enforce its use through relevant acts and regulations. Mandatory use means that the standards are part of the requirements for producing a particular product. According to Blind (2013), the implementation of standards is deemed important by a few organisations as it is directly linked to their core business strategy and has a clear impact on their performance. On the other hand, others may use standards from a narrower perspective, only for specific purposes or activities. However, there are also some organisations or firms that do not use them at all and even consider them to be a burden as they involve additional costs.

\subsubsection{Impact of Standardisation}

Impacts usually result from an intervention or an intermediate outcome (Peersman, 2015). Standardisation or the implementation of standards are normally not the primary or direct causes of impacts. Since a standard enables companies to share innovation, whilst at the same time developing good market practices, it usually works in tandem with innovation and is also a means of disseminating it (Hawkins, Blind, \& Page, 2017). Therefore, crucially, standards often facilitate impacts that arise, rather than producing direct impacts themselves.

Standardisation could have a positive influence on economic growth due to the resulting improved diffusion of knowledge (Blind, 2004). Moreover, Blind explains that standards play a vital role in our increasingly globalised world, making a greater contribution to economic growth than patents or licences. Exportoriented sectors use standards as a strategy in opening up new markets. They not only reduce the time needed to make market inventions and develop innovative technologies, but in the first place facilitate the marketing itself; e.g., by creating critical masses or collecting the support of all relevant stakeholders (Blind, 2013).

There is a large body of literature which reports the positive impacts of the implementation of standards on different performance measures (Manders, 2015; Verlag, 2000). Moreover, there are many types of impact from the implementation of standard classification. Tsiotras and Gotzamani (1996) and Prates and Caraschi (2014) divided the impact of the implementation of ISO 9001 into internal and external ones, while Sunarya et al. (2015) differentiated the impact of standardisation into tangible and intangible aspect. Moreover, Bellina et al. (2002) classified the impact of standardisation into six areas: 1) trade and free movement; 2) competitiveness and quality; 3) innovation; 4) health and safety workers; 5) consumers; and 6) the environment.

\subsection{Previous Studies}

In line with the increasing number of halal-certified companies in the world, the level of research into halal food certification is also constantly increasing. From the literature review, many studies have been identified which address the roles and 
impacts of halal certificates and halal logos in Malaysia (Shafie \& Othman, 2006; Ahmad, Wahid, \& Kastin, 2007; Aziz \& Chok, 2013; Batu \& Regenstein, 2014; Latief et al., 2014; Pickering, 2015; Talib, Hamid \& Chin, 2015; Talib et al., 2016; Atikah, 2016; Kaur, 2016; Asa, 2017; Rafiki, 2019). However, Aziz and Chok (2013) argue that research into halal food and certification is still at an early stage and lacks theoretical applications.

The discrepancy in the theoretical application of halal food certification research is due to the fact that most halal researchers have focused more on the consumer perspective (Mohamed, Shamsudin, \& Rezai, 2013; Aziz \& Chok, 2013; Nawi \& Nasir, 2014). In addition, Talib, Hamid, and Chin (2015) state that there is limited literature on halal certification and standards, especially in relation to the implementation of MS1500.

\subsection{Conceptual Framework}

There are many frameworks for conducting implementation research. However, WHO (2014) state that the logical framework approach (LFA) is the most suitable. This is because it has the power to communicate the essential elements of a complex project clearly and succinctly throughout the project cycle (World Bank, 2004). LFA is normally used to develop the overall design of a project, to improve project implementation monitoring and to strengthen project evaluation (Brown, 2016).

Moreover, Brown explains that LFA shows just the pathway with which a programme in connected and presents the intervention in a 'logical', sequential way. It is linear and hence only depicts components which are directly linked to a programme. In LFA, all 'activities' lead to 'outputs'. These 'outputs' eventually lead to 'outcomes', which will produce 'goals'. It is a one-way process and there are no cycles or feedback loops. LFA is usually designed bottom-up, using a descriptive model; e.g., 'If we plan to do X, then this will give Y result'. The LFA for this study is illustrated in Figure 1.

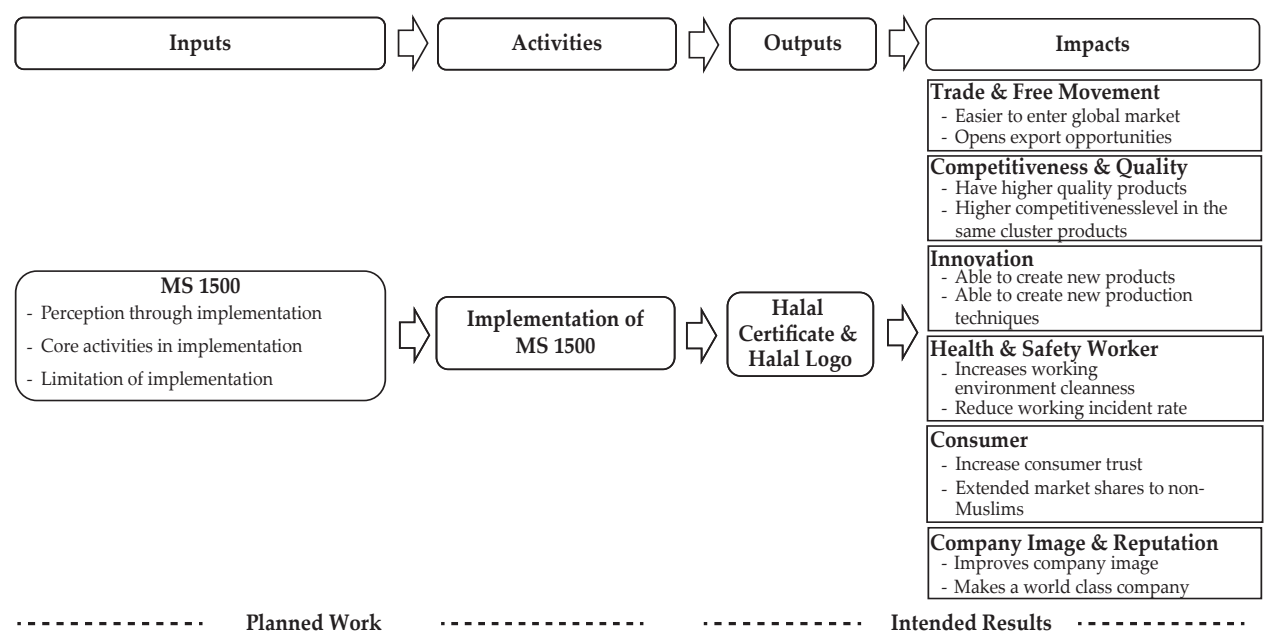

Figure 1. 
In Figure 1, it can be seen that after several implementation activities, MS1500 as an input will produce halal certificates and logos as an output. The implementation itself is affected by: (1) the perception of the halal food industry as the implementer; (2) certain core activities in the daily implementation; and (3) the limitations or barriers faced by the industry in the implementation of MS1500. A series of activities this implementation is expected to have several intended positive impacts on the industry, namely: 1) trade and free movement; 2) competitiveness and quality; 3) innovation; 4) health and safety workers; 5) consumers; and 6) company image and reputation.

\section{Methodology}

The positivist research paradigm and philosophy were chosen for use in the study, with a cross-sectional design in which the details are presented in the form of the logical framework approach (see Figure 1). The nature of the investigation is a non-experimental study. In addition, a quantitative method was adopted, with purposive sampling and a criterion strategy.

\subsection{Data}

Since MS 1500 is a basic reference used by JAKIM in issuing halal certificates, it is assumed that all the companies in the halal food industry already have such certificates and by default have automatically implemented the MS. Therefore, the scope of the population for the study comprises food and beverages companies in Malaysia which already have halal certificates and logos. As of 25th August 2018, there were 5,338 such companies in Malaysia.

The primary data were collected by a survey using a structured questionnaire which was delivered and collected directly by the researcher. The companies that participated in the survey were ones which had taken part in halal exhibitions or halal food festivals. In addition, the criteria for survey participation were that the companies currently employed and were involved in service delivery in the halal food industry.

The data collection time frame was from September 2018 to September 2019. The coverage area for companies and survey participants was 12 out of the 13 states in Malaysia, with the exception of Perlis. The study also covered two out of the three federal territories in the country, with the exclusion of Putrajaya.

Out of the 225 distributed questionnaires, 215 were returned (a 95.55\% response rate), of which three were incomplete. Therefore, 212 completed questionnaires $(94.22 \%)$ were ready to be utilised in the data analysis process. The sample size was slightly higher than 200, with the sample requirement for a CB-SEM analysis being 100-400 (Bentler \& Chou, 1987; Hair et al., 2010; Hair et al., 2014; Kline, 2011; Weston \& Gore, 2006). 


\subsection{Model Development}

Based on the conceptual framework, the proposed model is illustrated in Figure 2.

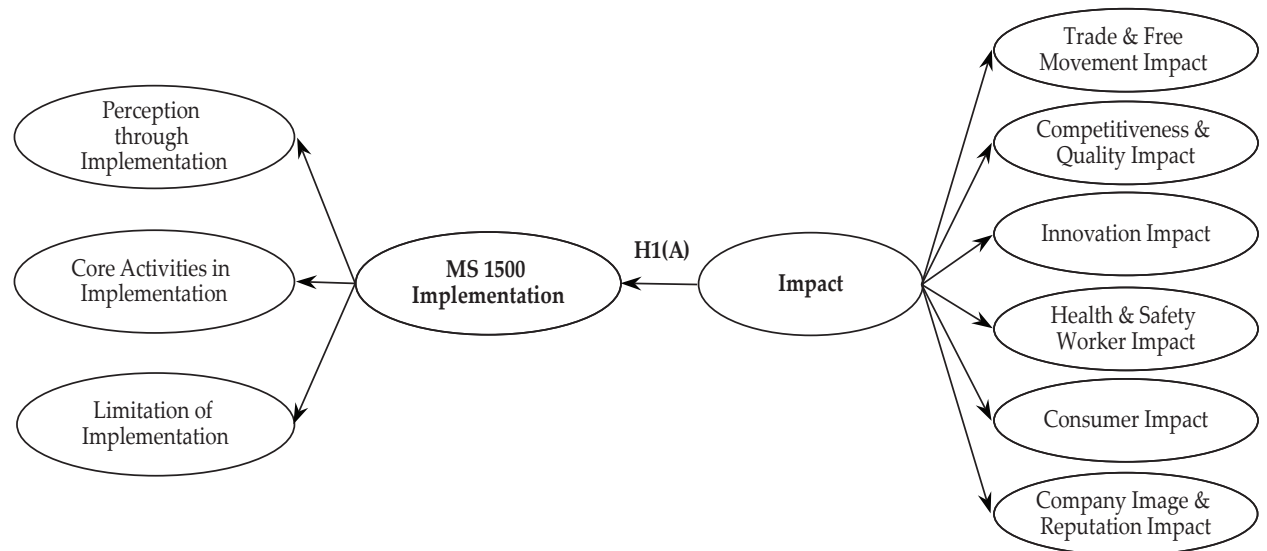

Figure 2.

Proposed Model

The model consists of two major parts: (1) the implementation itself; and (2) the impact of the implementation. The first part refers to Peters et al. (2013), while the second adopts and modifies the six types of standardisation impact of Bellina et al. (2002).

\subsection{Research Analysis Steps}

The flow chart of the research analysis process can be seen on Figure 3.

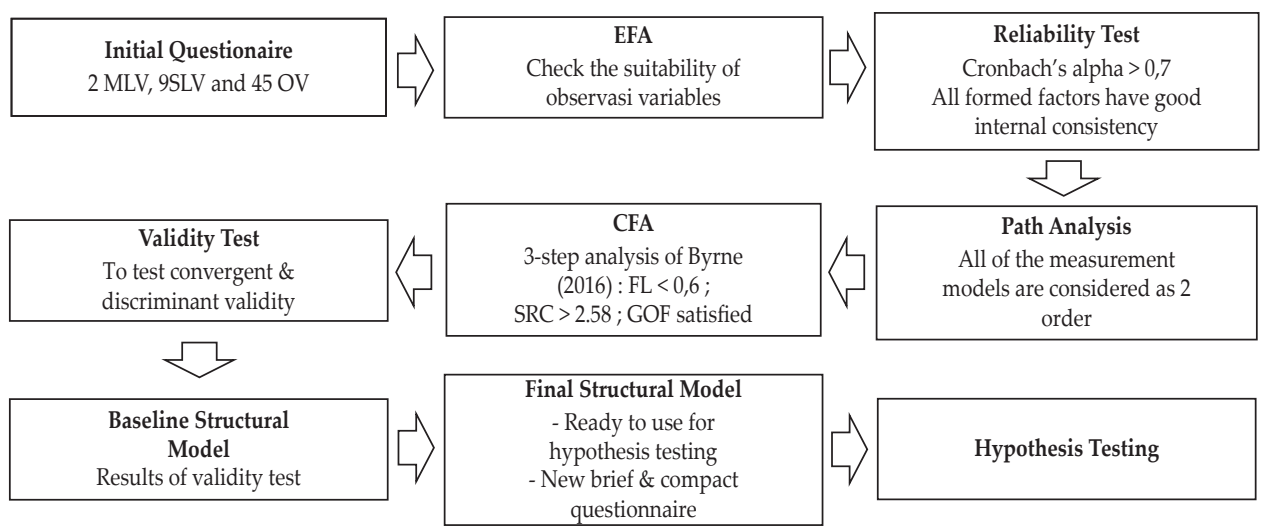

Note: MLV = Main Latent Variable; SLV = Sub-Latent Variable; OV = Observed Variable; EFA = Exploratory Factor Analysis; CFA = Confirmatory Factor Analysis; FL = Factor Loading; SRC = Standardized-Residual-Covariance; GOF $=$ Goodness of Fit

Figure 3. 
The study began with descriptive statistical analysis of the main research attributes in the questionnaire. Since a standardised theory of the implementation of a halal standard has yet to be developed, the questionnaire was designed based on several different studies regarding the implementation of a general standard (Fixsen et al., 2005; Manders, 2015; Talib, Hamid, \& Chin, 2015).

Based on the proposed conceptual framework (see Figure 2), the main research attributes were divided into two main latent variables (MLV): (1) implementation, consisting of three sub-latent variables (SLVs); and (2) impact, consisting of six SLVs. Each implementation SLV consisted of seven observed variables (OVs) and each impact SLV consisted of four OVs. Therefore, the main research attributes comprised two MLVs, nine SLVs and 45 OVs.

The next step was exploratory factor analysis (EFA) and a reliability test. By performing EFA, a significant cluster of indicators or observed variables was expected to be broken down into certain sets, which were divided and eventually represented by certain variables (Hair et al., 2010). EFA is conducted to check whether the predefined factors were correct and suitable for use as factors. The naming of the predefined factors was conducted based on the chosen pertinent theory or similar research findings.

To elaborate the implementation of MS1500, the study followed and modified the findings of Peter, Trans \& Adam (2013). In addition, to analyse the impact, the six types of impacts of standardisation of Bellina et al. (2002) were adopted and modified. Therefore, there were nine predefined factors (sub-latent variables): 1) implementation-A (perception of implementation); 2) implementation-B (core activities in implementation); 3) implementation-C (limitations of implementation); 4) impact-A (trade and free movement); 5) Impact-B (competitiveness and product quality); 6) Impact-C (innovation); 7) Impact-D (clean and safe production process); 8) Impact-E (consumers); and 9) Impact-F (companies' image and reputation).

Before proceeding to the EFA, the MSA (measure of sampling adequacy) indicators were evaluated. These consisted of Bartlett's test of sphericity, the KMO test and anti-image correlation test. The principal component analysis (PCA) method was chosen to extract the data, and the varimax rotation method to rotate the factor matrix. Furthermore, to test the internal consistency of the EFA results, Cronbach's $\alpha$ test was performed as a reliability test. Nunnally (1978) recommends that a Cronbach's $\alpha$ above 0.70 is good; above 0.80 is better; and above 0.90 is best.

The next step was covariance-based structural equation modelling (CB-SEM), consisting of confirmatory factor analysis (CFA), a validity test and structural model analysis. Before starting the CFA, a path diagram design based on the reliable results of EFA was needed. The objective of CFA is to test whether the data fit a hypothesised measurement model (Preedy \& Watson, 2009).

Since each of the two MLVs (implementation and impact) consist of several SLVs, all the path diagrams of the measurement models were considered as "second order measurement models". Consequently, each CFA model started with the first order initial model, followed by the first order final model and the second order initial model, and ending with the second order final model. The whole CFA process only stops when the goodness of fit (GOF) criterion is fulfilled and the proper model is obtained (see Table 1). 
Table 1.

Recommended Values of Goodness of Fit Criteria (Hair et al., 2010)

\begin{tabular}{lc}
\hline Measure & Threshold Values \\
\hline RMSEA & Absolute Fit Level \\
GFI & Less than 0.08 \\
P- Value & 0.90 and above \\
\hline & P- value $<0.05$ \\
\hline AGFI & Incremental Fit Level \\
CFI & 0.90 and above \\
TLI & 0.90 and above \\
NFI & 0.90 and above \\
\hline & 0.90 and above \\
\hline $\mathrm{CMIN} / \mathrm{df}$ & Parsimonious Fit Level \\
$\mathrm{SMC}\left(\mathrm{R}^{2}\right)$ & Less than 5.0 \\
\hline
\end{tabular}

The CFR model fit does not guarantee that convergent and discriminant validity are automatically achieved. Therefore, it is important to perform a validity test to obtain the values of composite reliability (CR), average variance extracted (AVE), maximum shared squared variance (MSV) and average shared squared variance (ASV). Hair et al. (2014) state that CR must be greater than AVE, and that AVE must be greater than 0.5 . In addition, to reach a good discriminant validity, MSV and ASV must be lower than AVE. On certain occasions, researchers must face the issue of collinearity if there is a high correlation between two latent variables (Kock \& Lynn, 2012). To solve such an issue, Kock and Lynn (2012) suggest several possible steps that can be taken: (1) OV removal; (2) OV re-assignment; (3) LV removal; (4) LV aggregation; and (5) hierarchical analysis.

Furthermore, the baseline structural model can be designed based on the final results of CFA that have been tested for their validity and reliability. The model is then evaluated using the three-step analysis of Byrne (2016), which consists of: (1) an item-deletion process based on the factor loading value; (2) detecting model misspecification issues using modification indices (MI) and standardised residual covariance (SRC); and (3) examination of the goodness-of-fit (GOF) statistics (fitness indices). Once all the GOF criteria are fulfilled, a final structural model will be achieved and can be considered to fit the research data (observed variables).

This final structural model is then ready to be used for the hypothesis testing, which enables measurement of the relationship between the latent variables. According to Byrne (2016), to ensure whether the hypotheses in the model need to be supported or rejected, the recommended critical ratio (CR) and $P$ values need to be considered. The value of the $\mathrm{CR}$ should be greater than that from the $\mathrm{t}$-table (Hair et al., 2014). Therefore, for $\mathrm{p}<0.05$, the $C R$ should be higher than 1.96 , while for $\mathrm{p}<0.01$ it should be higher than 2.58 .

The study hypotheses are:

HO : Implementation of MS1500 does not positively affect its impact.

HA : Implementation of MS1500 positively affects its impact. 


\subsection{Method}

Once the factors affecting the implementation of MS1500 and its impacts were identified through reliable EFA results, covariance-based structural equation modelling (CB-SEM) was utilised as an analysis method. This consisted of confirmatory factor analysis, a validity test and structural model analysis. According to Zhang, Dawson, and Kline (2020), CB-SEM is a flexible and compelling data analysis method in which hypothetical constructs are estimated as common factors which are assumed to cause their indicators (observed variables).

CB-SEM has several attractive features relative to other frequently used analytical methods. First, it is an integration of several multivariate techniques; for example, regression analysis, path analysis and confirmatory factor analysis (Cheung, 2015). Second, CB-SEM can account for measurement errors in both the predictive and outcome variables (Grewal, Cote, \& Baumgartner, 2004), providing a more accurate estimate of the model parameters and effects and offering a better control for both the measured and latent factors (Cheung \& Lau, 2008; Hoyle \& Smith, 1994). Third, it allows a series of contrasting models to be tested, interpreted and compared quantitatively (Mitchell, 1992). In doing so, it can help researchers identify the best approximating models that are theoretically precise and parsimonious (Burnham \& Anderson, 2013). However, there are several conditions which need to be considered before performing CB-SEM: (1) it involves special identification requirements that can be difficult to satisfy; (2) technical problems in the analysis, such as non-convergence of iterative estimation, can be encountered; and (3) a large sample size is needed (Bentler \& Chou, 1987; Hair et al., 2010; Kline, 2011; Weston \& Gore, 2006).

CB-SEM is used to discover whether the theoretical model can explain the sample data well, essentially testing the suitability of the model used (Byrne, 2016; Hair et al., 2010; Hair et al., 2014). Therefore, CB-SEM was considered to be an appropriate data analysis method for use in the study. Since SPSS was chosen as the basic tool to analyse the dataset and as AMOS (Analysis of Moment Structures) is compatible with SPSS, it was decided to use AMOS to perform the CB-SEM.

\section{RESULTS AND ANALYSIS}

\subsection{Results}

\subsubsection{Descriptive Statistical Analysis}

Table 2 shows the descriptive analysis of the respondents' profiles. As expected, out of the 212 respondents, most were Muslim (86.79\%) and Malay (84.43\%). However, even if they were Muslim, there was no guarantee that they automatically understood about halal matters. From the data collected, it was found that the number of respondents who had acquired halal knowledge from attending halal training courses was greater than the number of self-learning ones.

Based on their job titles, it is found that a small majority of the respondents were "halal executives" (25.94\%), followed by "owners" (23.58\%). Based on their highest level of education, the majority of the respondents were bachelor degree holders (58.02\%) and diploma holders (25.94\%). Additionally, with regard to career length, it was found that $52.36 \%$ of the respondents had worked for less than 3 years and only $7.08 \%$ for more than 15 . 
Table 3 shows a descriptive analysis of the company profiles. Based on their year of establishment, it was found that most $(41.04 \%)$ were relatively new companies that had started their business less than a decade ago. Only $3.30 \%$ of the companies had been established for more than 40 years. In addition, based on legal status, $81.13 \%$ were private limited companies and $11.32 \%$ were sole proprietorship companies.

Moreover, based on annual turnover, $90.09 \%$ of the companies were SMEs, $5.20 \%$ were LLCs and $4.71 \%$ MNCs. In terms of the number of permanent employees, it was found that $87.26 \%$ were classed SMEs, $8.03 \%$ LLCs and $4.71 \%$ MNCs. These results indicate that there were several companies with more than 200 permanent employees but with an annual turnover of less than RM 50 million.

The final data related to the company profiles were halal certificate renewal and length of implementation of MS1500. It was found that the majority of the companies $(70.75 \%)$ preferred to renew their halal certificate every two years, and that most (51.89\%) had only implemented MS1500 for a fairly short period of time (1-3 years).

Furthermore, Table 4 shows the descriptive statistical analysis of the main research attributes. From the mean value, it is seen that most of the respondents agreed that perception and core activities in the implementation of MS1500 were the most important aspects in an implementation study.

Table 2.

\section{Respondent Profiles}

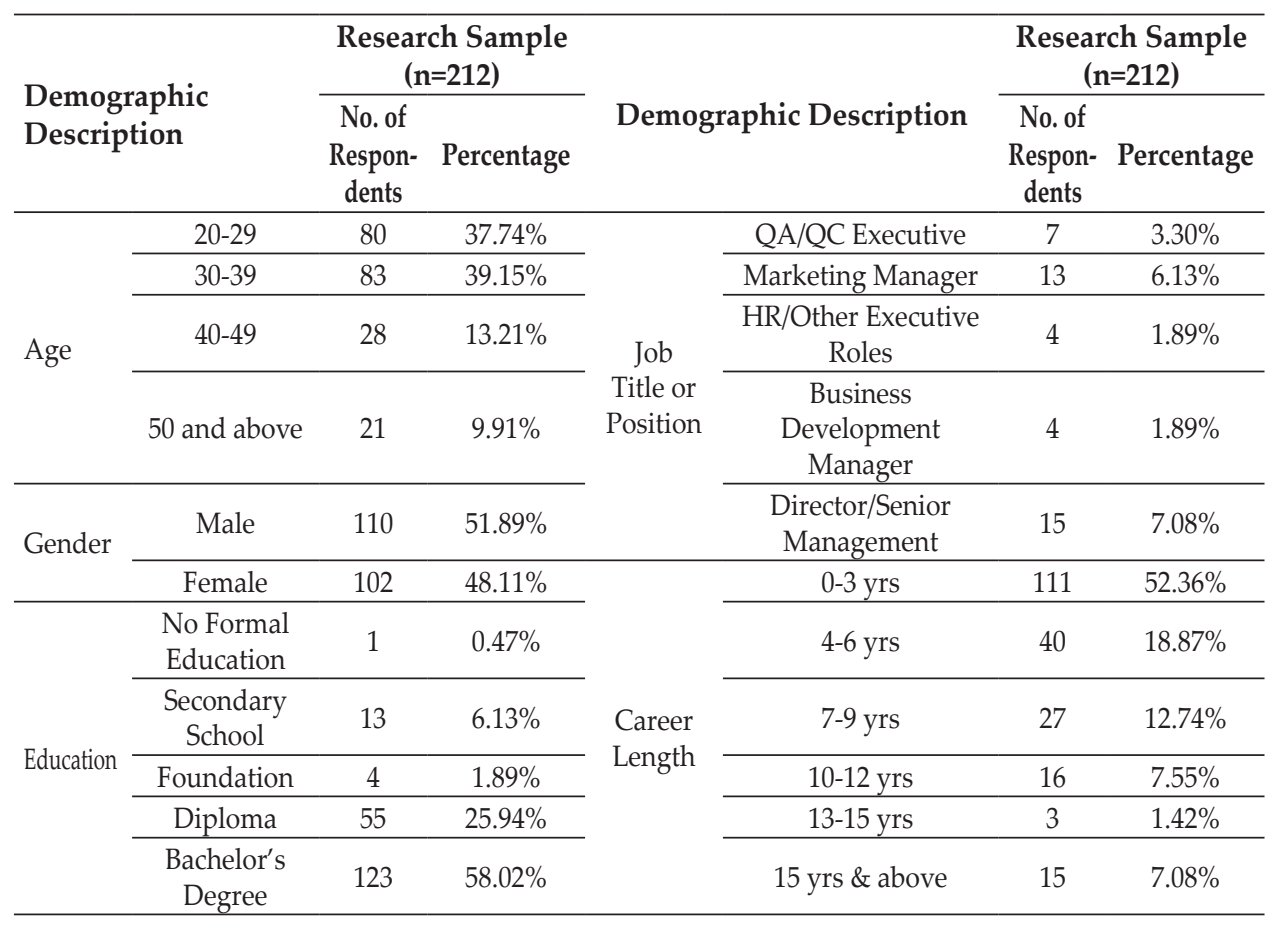


Table 2.

Respondent Profiles (Continued)

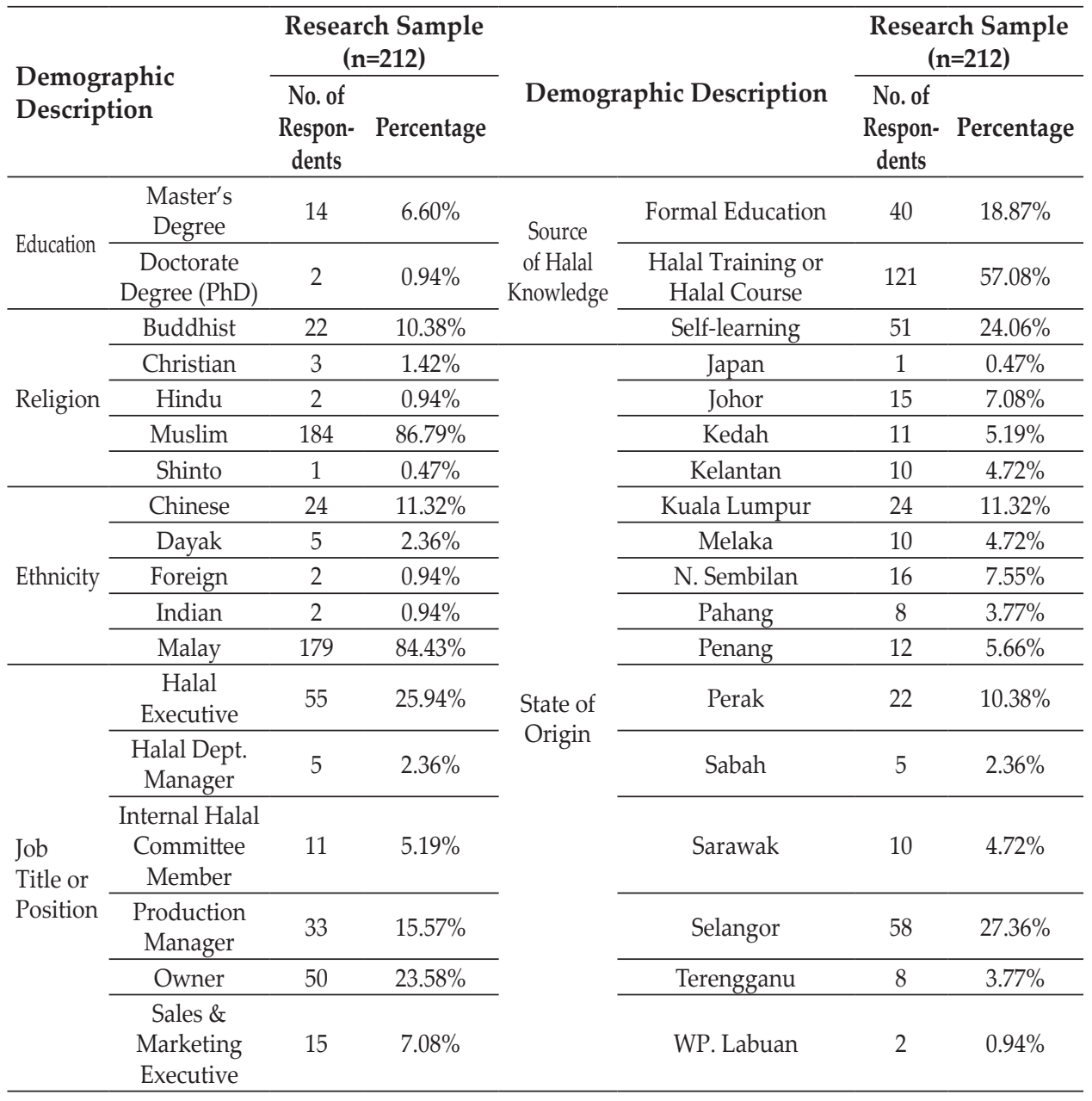


Table 3.

Company Profiles

\begin{tabular}{|c|c|c|c|}
\hline \multirow{2}{*}{ Company Profile } & & \multicolumn{2}{|c|}{ Research Sample $(\mathrm{n}=212)$} \\
\hline & & $\begin{array}{c}\text { No. of } \\
\text { Respondents }\end{array}$ & Percentage \\
\hline \multirow{14}{*}{$\begin{array}{l}\text { Company Operational } \\
\text { Location }\end{array}$} & Johor & 13 & $6.13 \%$ \\
\hline & Kedah & 8 & $3.77 \%$ \\
\hline & Kelantan & 5 & $2.36 \%$ \\
\hline & Kuala Lumpur & 15 & $7.08 \%$ \\
\hline & Melaka & 14 & $6.60 \%$ \\
\hline & N. Sembilan & 13 & $6.13 \%$ \\
\hline & Pahang & 4 & $1.89 \%$ \\
\hline & Penang & 7 & $3.30 \%$ \\
\hline & Perak & 15 & $7.08 \%$ \\
\hline & Sabah & 2 & $0.94 \%$ \\
\hline & Sarawak & 8 & $3.77 \%$ \\
\hline & Selangor & 102 & $48.11 \%$ \\
\hline & Terengganu & 5 & $2.36 \%$ \\
\hline & WP Labuan & 1 & $0.47 \%$ \\
\hline \multirow{7}{*}{ Year of Establishment } & Before 1960 & 7 & $3.30 \%$ \\
\hline & 1960-1970 & 6 & $2.83 \%$ \\
\hline & 1971-1980 & 9 & $4.25 \%$ \\
\hline & 1981-1990 & 17 & $8.02 \%$ \\
\hline & $1991-2000$ & 28 & $13.21 \%$ \\
\hline & 2001-2010 & 58 & $27.36 \%$ \\
\hline & 2011-2020 & 87 & $41.04 \%$ \\
\hline \multirow{5}{*}{ Company Size } & Micro Company & 50 & $23.58 \%$ \\
\hline & Small Company & 118 & $55.66 \%$ \\
\hline & Medium Company & 17 & $8.02 \%$ \\
\hline & Large Local Company (LLC) & 17 & $8.02 \%$ \\
\hline & Multinational Company (MNC) & 10 & $4.72 \%$ \\
\hline \multirow{4}{*}{ Legal Status } & Partnership & 8 & $3.77 \%$ \\
\hline & Private Limited Company & 172 & $81.13 \%$ \\
\hline & Public Limited Company & 8 & $3.77 \%$ \\
\hline & Sole Proprietorship & 24 & $11.32 \%$ \\
\hline \multirow{4}{*}{ Annual Turnover } & Less than RM 300,000 & 69 & $32.55 \%$ \\
\hline & RM 300,000 - RM 15 Million & 102 & $48.11 \%$ \\
\hline & RM 15 - 50 Million & 20 & $9.43 \%$ \\
\hline & Over RM 50 Million & 21 & $9.91 \%$ \\
\hline \multirow{3}{*}{$\begin{array}{l}\text { Halal Certificate } \\
\text { Renewal }\end{array}$} & Every 1 year & 35 & $16.51 \%$ \\
\hline & Every 2 years & 150 & $70.75 \%$ \\
\hline & Every 3 years & 27 & $12.74 \%$ \\
\hline Years of Halal & 1-3 Years & 110 & $51.89 \%$ \\
\hline Certificate & 4-6 Years & 40 & $18.87 \%$ \\
\hline Implementation & 7-9 Years & 62 & $29.25 \%$ \\
\hline
\end{tabular}


Table 4.

Descriptive Statistics - Main Research Attributes

\begin{tabular}{lcc}
\hline Sub-Section Questionnaire & Mean & Standard Deviation \\
\hline Perception through Implementation (Imple-A) & 4.34 & 0.68 \\
Core Activities (Imple-B) & 4.34 & 0.67 \\
Limitations of Implementation (Imple-C) & 4.03 & 0.72 \\
Trade \& Free Movement (Impact-A) & 4.26 & 0.69 \\
Competitiveness \& Quality of Product (Impact-B) & 4.16 & 0.73 \\
Innovation (Impact-C) & 3.98 & 0.76 \\
Clean \& Save Production Process (Impact-D) & 4.13 & 0.69 \\
Consumers (Impact-E) & 4.38 & 0.64 \\
Company Image \& Reputation (Impact-F) & 4.29 & 0.68 \\
\hline
\end{tabular}

\subsubsection{Exploratory Factor Analysis (EFA) and Reliability Test}

The summary of EFA shown in Table 5 indicates that two factors are formed (extracted) from each predefined implementation factor. These results demonstrate that all the observed variables on each predefined implementation factor can be explained by two different factors. Nevertheless, a different approach is involved to one of these, namely perception (Imple-A). Even though there are two formed factors, one of these only has one observed variable, namely ImpleA5 (the holistic and continuous implementation of MS1500 will incur extra costs).

Considering the recommendation of Tabachnick and Fidell (2007) that the minimum requirement for something to be labelled as a factor is that it has at least three observed variables, it was decided to remove this second factor. After rerunning the EFA with only six remaining observed variables, it was found that only one factor was formed, which was termed "perception of implementation". Consequently, the EFA turned the three predefined implementation factors (perception, core activity and limitations) into five formed factors, namely perception of implementation (POI); pre-service and in-service activity (PIA); halal control system activity (HCSA); owner management and employee limitations (OMEL); and finance and regulation limitations (FRL).

Moreover, to test the internal consistency of the EFA results, a Cronbach's $\alpha$ test was performed. As can be seen from the complete reliability test results in Table 6, all the Cronbach's $\alpha$ values of the 14 formed factors are above 0.7 (between 0.785 and 0.932 ). 
Table 5.

EFA Summary

\begin{tabular}{|c|c|c|c|c|c|c|c|}
\hline \multirow{2}{*}{$\begin{array}{l}\text { Pre- } \\
\text { Defined } \\
\text { Factor }\end{array}$} & \multirow[b]{2}{*}{$\begin{array}{l}\text { Number of } \\
\text { Variables }\end{array}$} & \multirow[b]{2}{*}{ KMO } & \multirow[b]{2}{*}{$\begin{array}{l}\text { Communalities } \\
\text { Extraction }\end{array}$} & \multirow{2}{*}{$\begin{array}{l}\text { Number of } \\
\text { Eigenvalues } \\
(\mathrm{EV})>1\end{array}$} & \multirow{2}{*}{$\begin{array}{c}\text { Number } \\
\text { of } \\
\text { Factors } \\
\text { Formed } \\
\end{array}$} & \multicolumn{2}{|c|}{ Formed Factor } \\
\hline & & & & & & Factor-1 & Factor-2 \\
\hline Imple-A & 7 & 0.851 & $>0.5$ & 2 & 2 & $\begin{array}{c}\text { POI (Var1-4, } \\
\text { Var6-7) }\end{array}$ & $\begin{array}{l}\text { TAKE OUT } \\
\text { (Var5) }\end{array}$ \\
\hline Imple-B & 7 & 0.775 & $>0.5$ & 2 & 2 & $\begin{array}{l}\text { PIA (Var1 to } \\
\text { Var4) }\end{array}$ & $\begin{array}{l}\text { HCSA } \\
\text { (Var5 to } \\
\text { Var7) }\end{array}$ \\
\hline Imple-C & 7 & 0.793 & $>0.5$ & 2 & 2 & $\begin{array}{c}\text { OMEL } \\
\text { (Var4 to } \\
\text { Var7) }\end{array}$ & $\begin{array}{l}\text { FRL (Var1 } \\
\text { to Var3) }\end{array}$ \\
\hline Impact-A & 4 & 0.851 & $>0.5$ & 1 & 1 & $\begin{array}{c}\text { TFM (Var1 } \\
\text { to Var4) }\end{array}$ & None \\
\hline Impact-B & 4 & 0.821 & $>0.5$ & 1 & 1 & $\begin{array}{c}\text { CQP (Var1 } \\
\text { to Var4) }\end{array}$ & None \\
\hline Impact-C & 4 & 0.83 & $>0.5$ & 1 & 1 & $\begin{array}{l}\text { INNO (Var1 } \\
\text { to Var4) }\end{array}$ & None \\
\hline Impact-D & 4 & 0.78 & $>0.5$ & 1 & 1 & $\begin{array}{l}\text { CSPP (Var1 } \\
\text { to Var4) }\end{array}$ & None \\
\hline Impact-E & 4 & 0.79 & $>0.5$ & 1 & 1 & $\begin{array}{c}\text { CONS (Var1 } \\
\text { to Var4) }\end{array}$ & None \\
\hline Impact-F & 4 & 0.793 & $>0.5$ & 1 & 1 & $\begin{array}{c}\text { CIR (Var1 to } \\
\text { Var4) }\end{array}$ & None \\
\hline
\end{tabular}

Table 6.

Reliability Coefficients of the Formed (Extracted) Factors

\begin{tabular}{lcc}
\hline Factor Generated & $\begin{array}{c}\text { Cronbach's } \\
\text { Alpha }\end{array}$ & $\begin{array}{c}\text { No. of } \\
\text { Constructs }\end{array}$ \\
\hline Perception of Implementation (POI) & 0.868 & 6 \\
Pre-service \& In-service Activities (PIA) & 0.826 & 4 \\
Halal Control System Activities (HCSA) & 0.829 & 3 \\
Owner, Management or Employee Limitations (OMEL) & 0.828 & 3 \\
Limitation of Financial \& Regulation Factors (FRL) & 0.850 & 4 \\
Trade \& Free Movement (TFM) & 0.932 & 4 \\
Competitiveness \& Quality of Products (CQP) & 0.852 & 4 \\
Innovation (INNO) & 0.897 & 4 \\
Clean \& Safe Production Process (CSPP) & 0.895 & 4 \\
Consumers (CONS) & 0.857 & 4 \\
Company Image \& Reputation (CIR) & 0.785 & 4 \\
\hline Total & 0.965 & 44 \\
\hline
\end{tabular}

\subsubsection{Confirmatory Factor Analysis (CFA)}

The result of the CFA can be seen in Figures 4 and 5. In addition, a summary of the CFA process is shown in Table 7. 


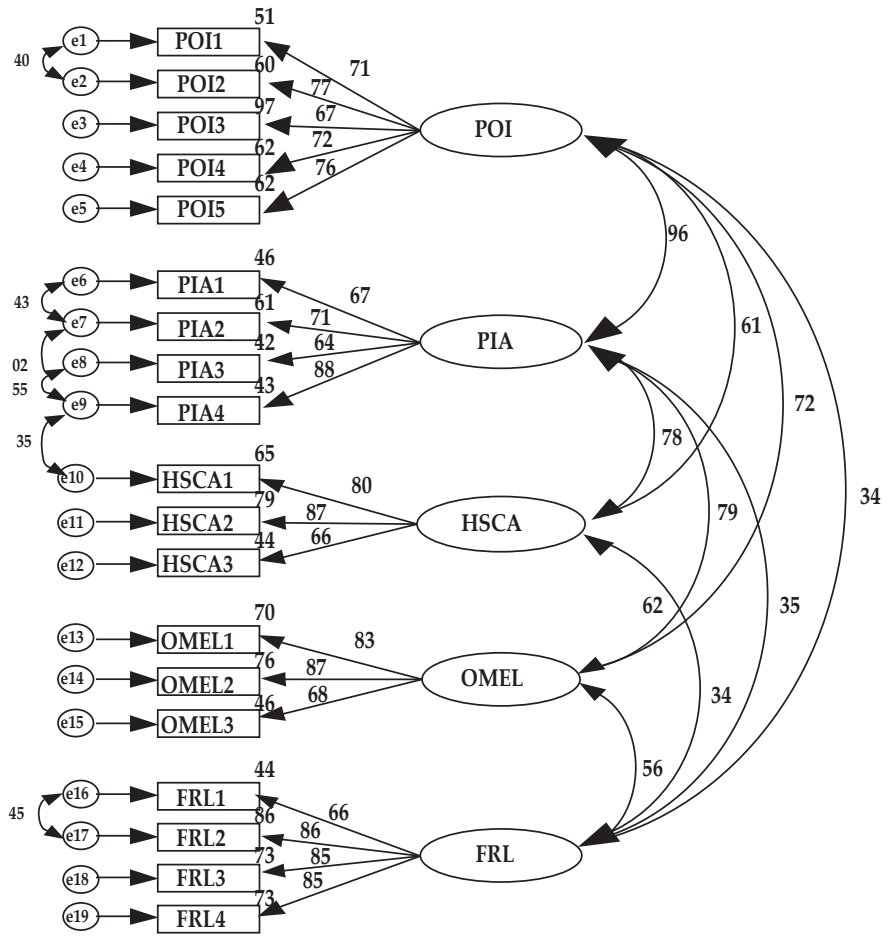

IMPLEMENTATION $1^{\text {ST }}$ ORDER FINAL MODEL

Fitness Indexes:

1. ChiSq $=234,226$

2. Df $=136$

3. P-value $=0,000$

4. $\mathrm{CMIN} / \mathrm{DF}=1,722$

5. GFI $=0,894$

6. TLI $=0,946$

7. CFI $=0,958$

8. RMSEA $=0,059$

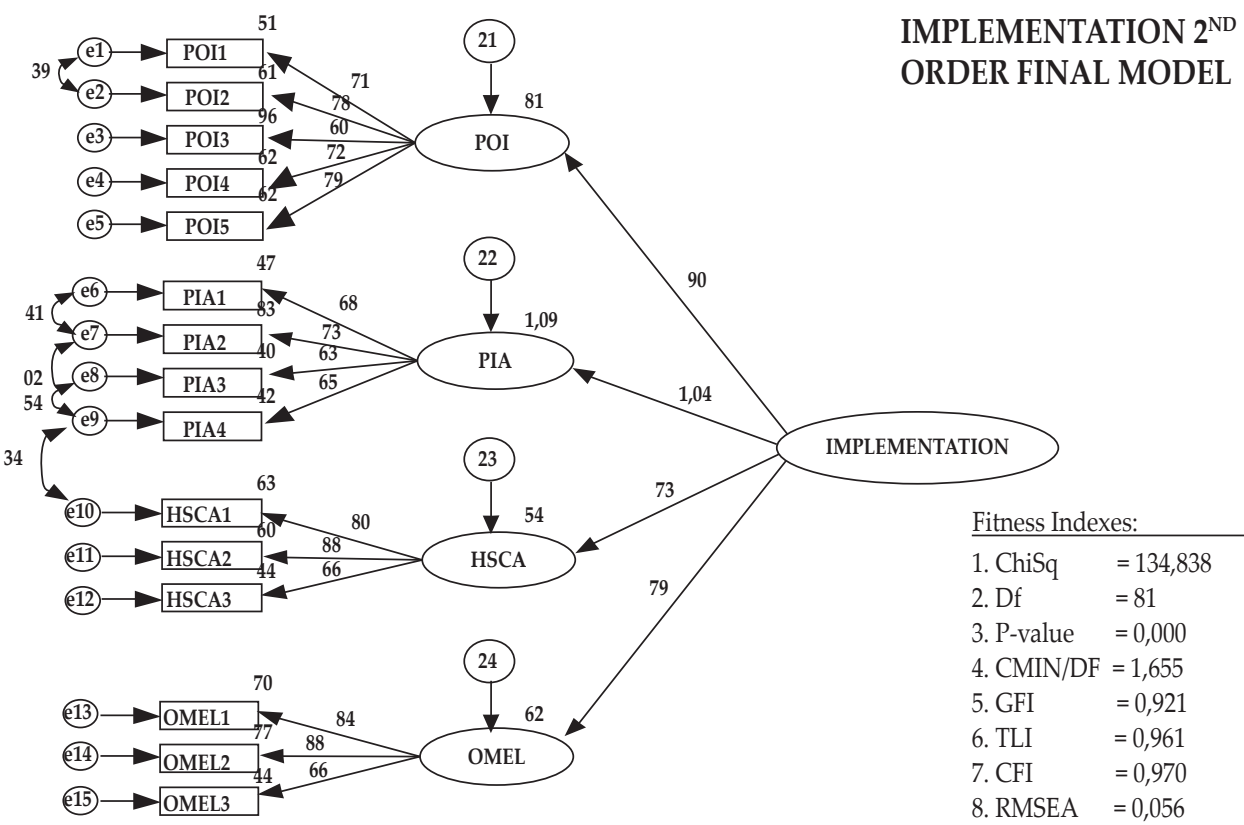

Figure 4.

CFA for Implementation 
As shown in Figure 4, it was found that for the MLV implementation there were four SLVs with a total of $15 \mathrm{OVs}$ remaining in the final second order measurement model. It was also found that pre-service and in-service activity (PIA) had the highest correlation with implementation (factor loading or FL= 1.04), and that halal control system activity (HCSA) had the lowest correlation with implementation $(\mathrm{FL}=0.73)$. Moreover, it was found that POI5 (the holistic and continuous implementation of MS 1500:2009 will incur extra costs) had the highest correlation with POI $(\mathrm{FL}=0.79)$ and POI3 (halal committee or halal department staff are preferably Muslim) had the lowest correlation with POI (FL = $0.60)$. For PIA, the highest correlation $(F L=0.73)$ related to PIA2 (the availability of internal dedicated and meticulous experts who can supervise all the stages of the implementation of MS 1500:2009 is important), and the lowest (FL = 0.63) to PIA3 (hygiene, sanitation and food safety are prerequisites in preparing halal food).

Figure 4 also shows that HCSA2 (halal-certified companies should have their own internal halal control systems with regular internal evaluation) has the highest correlation with HCSA (FL $=0.89$ ), while HCSA3 (companies need to practice all kinds of innovation after obtaining halal certification) has the lowest correlation with HCSA (FL = 0.66). Moreover, it was found that OMEL2 (employees' lack of skill and knowledge in food safety and halal food standards will hinder the implementation of MS 1500:2009) had the highest correlation with OMEL (FL = 0.87), and that OMEL3 (a limited number of employees who have understanding of halal food standards will hinder the implementation of MS 1500:2009) has the lowest $(\mathrm{FL}=0.66)$.

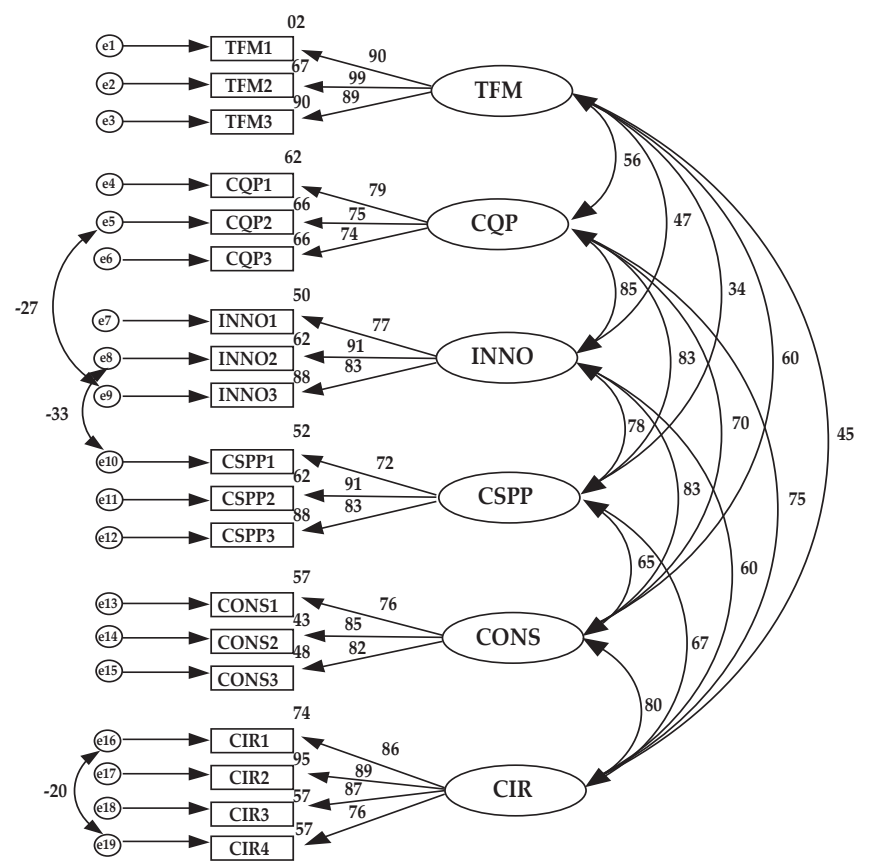

Figure 5.
IMPACT $1^{\text {ST }}$ ORDER FINAL MODEL
Fitness Indexes:

$\begin{array}{ll}\text { 1. ChiSq } & =226,590 \\ \text { 2. } \mathrm{Df} & =133 \\ \text { 3. } \mathrm{P} \text {-value } & =0,000 \\ \text { 4. CMIN/DF } & =1,854 \\ \text { 5. GFI } & =0,892 \\ \text { 6. TLI } & =0,953 \\ \text { 7. CFI } & =0,964 \\ \text { 8. } \text { RMSEA } & =0,064\end{array}$




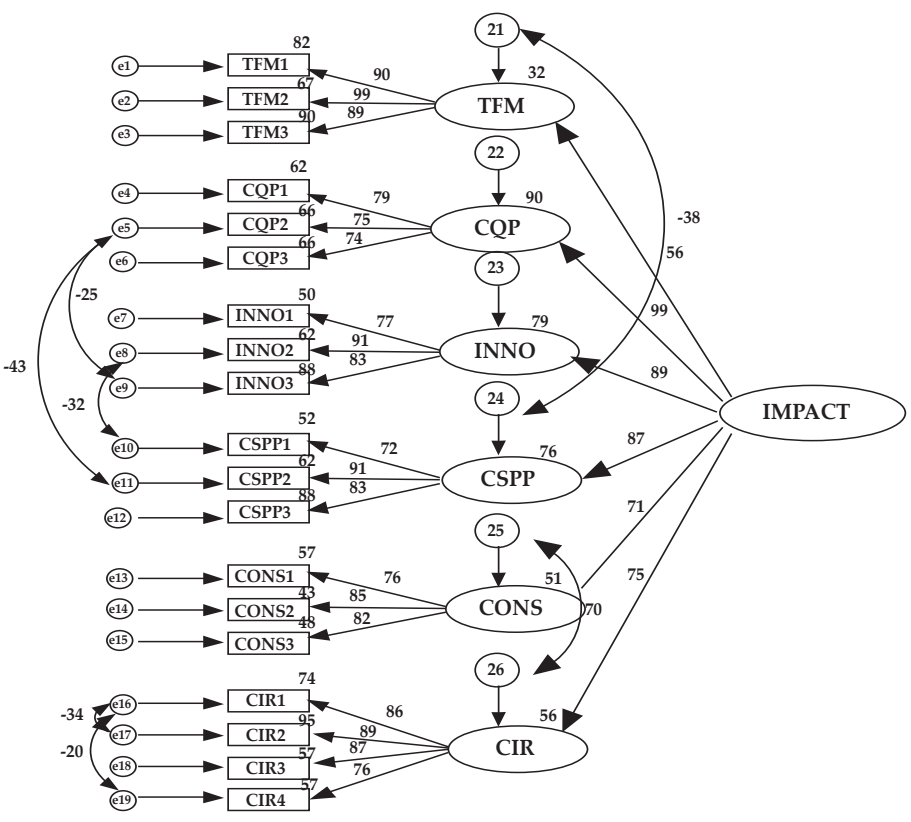

Figure 5.

CFA for Impact (Continued)
IMPACT $2^{\text {ND }}$ ORDER FINAL MODEL

\begin{tabular}{|c|c|}
\hline \multicolumn{2}{|c|}{ Fitness Indexes: } \\
\hline 1. ChiSq & $=244,046$ \\
\hline 2. Df & $=139$ \\
\hline 3. P-value & $=0,000$ \\
\hline 4. CMIN/DF & $=1,756$ \\
\hline 5. GFI & $=0,892$ \\
\hline 6. TLI & $=0,959$ \\
\hline 7. CFI & $=0,966$ \\
\hline 8. RMSEA & $=0,060$ \\
\hline
\end{tabular}

From Figure 5, it can be seen that for MLV impact, there are six SLVs with a total of 19 OVs remaining in the final second order measurement model. It was also found that competitiveness and quality product (CQP) had the highest correlation with impact $(\mathrm{FL}=0.99)$ and that trade and free movement (TFM) had the lowest $(F L=0.561)$. In addition, TFM2 (the impact of the implementation of MS 1500:2009 on increasing company competitiveness in the global market) had the highest correlation with TFM (FL $=0.93$ ) and TFM3 (the impact of the implementation of MS 1500:2009 on opening up export opportunities) the lowest $(\mathrm{FL}=0.89)$. For $\mathrm{CQP}$, the highest correlation $(\mathrm{FL}=0.78)$ corresponded to CQP1 (the impact of the implementation of MS 1500:2009 on increasing product quality) and the lowest (FL $=0.74$ ) to CQP3 (the impact of the implementation of MS 1500:2009 on increasing the competitiveness level of products in the international market).

Figure 5 also shows that INNO2 (the impact of the implementation of MS 1500:2009 on creating new production techniques) had the highest correlation with INNO $(F L=0.90)$, and that INNO1 (the impact of the implementation of OS 1500:2009 on creating innovation to achieve high quality halal products) had the lowest $(\mathrm{FL}=0.77)$. Furthermore, it was found that CSPP2 (the impact of the implementation of MS 1500:2009 on increasing worker safety) had the highest correlation with CSPP $(\mathrm{FL}=0.96)$ and that CSPP1 (the impact of the implementation of MS 1500:2009 on increasing the cleanliness of the production process) had the lowest $(\mathrm{FL}=0.72)$.

Figure 5 also indicates that CONS3 (the impact of the implementation of MS 1500:2009 on increasing consumer trust and loyalty) had the highest correlation with CONS $(\mathrm{FL}=0.86)$, and that CONS2 (the impact of the implementation of MS 
1500:2009 on increasing purchase interest, both from Muslim and non-Muslim consumers) had the lowest $(\mathrm{FL}=0.76)$. For CIR (the final sub-latent variable in impact), the highest correlation $(\mathrm{FL}=0.87)$ corresponds to CIR3 (the impact of the implementation of MS 1500:2009 on increasing company reputation, both locally and worldwide), with the lowest $(\mathrm{FL}=0.80$ ) referring to CIR2 (the impact of the implementation of MS 1500:2009 on increasing company credibility in society).

From Table 7, it is seen that there were two MLVs, 11 SLVs and 44 OVs at the beginning of the initial first order CFA model. By the end of the final second order model, there remained a total of two MLVs, ten SLVs and 34 OVs.

Table 7.

Summary of theCFA Process

\begin{tabular}{|c|c|c|c|c|c|}
\hline $\begin{array}{l}\text { Main Latent } \\
\text { Variable }\end{array}$ & $\begin{array}{l}\text { Initial } 1^{\text {st }} \\
\text { Order }\end{array}$ & $\begin{array}{l}\text { Final } 1^{\text {st }} \\
\text { Order }\end{array}$ & $\begin{array}{l}\text { Initial } 2^{\text {nd }} \\
\text { Order }\end{array}$ & $\begin{array}{l}\text { Final } 2^{\text {nd }} \\
\text { Order }\end{array}$ & Remarks \\
\hline Implementation & $5 \mathrm{SLV} 20 \mathrm{OV}$ & $\begin{array}{c}5 \text { SLV } 19 \\
\text { OV }\end{array}$ & 5 SLV $190 \mathrm{~V}$ & $\begin{array}{c}\text { 4 SLV } 15 \\
\text { OV }\end{array}$ & $\begin{array}{l}\text { Delete one SLV and five } \\
\text { OVs + Covariance of } \\
\text { several correlated errors }\end{array}$ \\
\hline Impact & $6 \mathrm{SLV} 24 \mathrm{OV}$ & $\begin{array}{c}\text { 6 SLV } 19 \\
\text { OV }\end{array}$ & $\begin{array}{c}\text { 6 SLV } 19 \\
\text { OV }\end{array}$ & $\begin{array}{c}\text { 6 SLV } 19 \\
\text { OV }\end{array}$ & $\begin{array}{l}\text { Delete one OV from } \\
\text { each of the five SLVs }\end{array}$ \\
\hline \multirow{2}{*}{ TOTAL } & $11 \mathrm{SLV}$ & $11 \mathrm{SLV}$ & $11 \mathrm{SLV}$ & $10 \mathrm{SLV}$ & \\
\hline & $44 \mathrm{OV}$ & $38 \mathrm{OV}$ & $38 \mathrm{OV}$ & $34 \mathrm{OV}$ & \\
\hline
\end{tabular}

Note: SLV = Sub Latent Variable; OV = Observed Variable

\subsubsection{Validity Test}

A summary of the validity test is shown in Table 8, where it can be seen that there are no issues related to composite reliability (CR) because all the CR values are greater than those of AVE. One AVE value was found to be smaller than 0.5, one ASV larger than AVE and seven MSV values higher than those of AVE. All the values in bold (as shown in Table 8) are those causing the issues which need to be solved in order to achieve good convergent and discriminant validity.

To solve some of the highlighted issues, a series of modifications was performed, based on the suggestion of Kock and Lynn (2012). From the re-examined validity test, it was found that only seven SLVs and 26 OVs remained, compared to the ten SLVs and $34 \mathrm{OVs}$ prior to the re-examination.

Table 8.

Summary of the Validity Test

\begin{tabular}{lcccccccc}
\hline Sub-Latent & \multicolumn{3}{c}{ Validity Test Based on CFA Results } & \multicolumn{6}{c}{ Re-examined Validity Test Results } \\
\cline { 2 - 9 } Variable & CR & AVE & MSV & ASV & CR & AVE & MSV & ASV \\
\hline POI & 0.844 & 0.522 & $\mathbf{0 . 9 0 3}$ & 0.48 & 0.865 & 0.562 & 0.516 & 0.34 \\
PIA & 0.729 & $\mathbf{0 . 4 5 4}$ & $\mathbf{0 . 9 0 3}$ & $\mathbf{0 . 5 6 5}$ & & & & \\
HCSA & 0.831 & 0.624 & 0.612 & 0.372 & 0.837 & 0.634 & 0.396 & 0.29 \\
OMEL & 0.839 & 0.638 & 0.626 & 0.462 & 0.84 & 0.639 & 0.516 & 0.401 \\
TFM & 0.935 & 0.828 & 0.318 & 0.221 & 0.936 & 0.829 & 0.245 & 0.192 \\
CQP & 0.803 & 0.577 & $\mathbf{0 . 7 9 7}$ & 0.571 & & & & \\
INNO & 0.874 & 0.7 & $\mathbf{0 . 7 9 7}$ & 0.481 & 0.882 & 0.653 & 0.616 & 0.419 \\
CSPP & 0.89 & 0.732 & 0.687 & 0.446 & 0.888 & 0.729 & 0.616 & 0.388 \\
\hline
\end{tabular}


Table 8.

Summary of the Validity Test (Continued)

\begin{tabular}{lcccccccc}
\hline \multirow{2}{*}{$\begin{array}{l}\text { Sub-Latent } \\
\text { Variable }\end{array}$} & \multicolumn{3}{c}{ Validity Test Based on CFA Results } & \multicolumn{5}{c}{ Re-examined Validity Test Results } \\
\cline { 2 - 9 } & CR & AVE & MSV & ASV & CR & AVE & MSV & ASV \\
\hline CONS & 0.853 & 0.66 & $\mathbf{0 . 7 3 8}$ & 0.447 & & & & \\
CIR & 0.895 & 0.681 & $\mathbf{0 . 7 3 8}$ & 0.471 & 0.902 & 0.649 & 0.434 & 0.348 \\
\hline
\end{tabular}

Note: Composite Reliability (CR), Average Variance Explained (AVE); Maximum Shared Squared Variance (MSV); Average Shared Squared Variance (ASV)

\subsubsection{Structural Model Analysis}

Figure 6 presents the structural model design based on the final results of the CFA tested for their validity and reliability. This is termed the 'baseline structural model'. The fitness index for the model indicates that it is not yet fit or appropriate because the values of CMIN/df $(2.017>2.00)$ and GFI $(0.820<0.9)$ still do not fulfil the GOF recommended values.

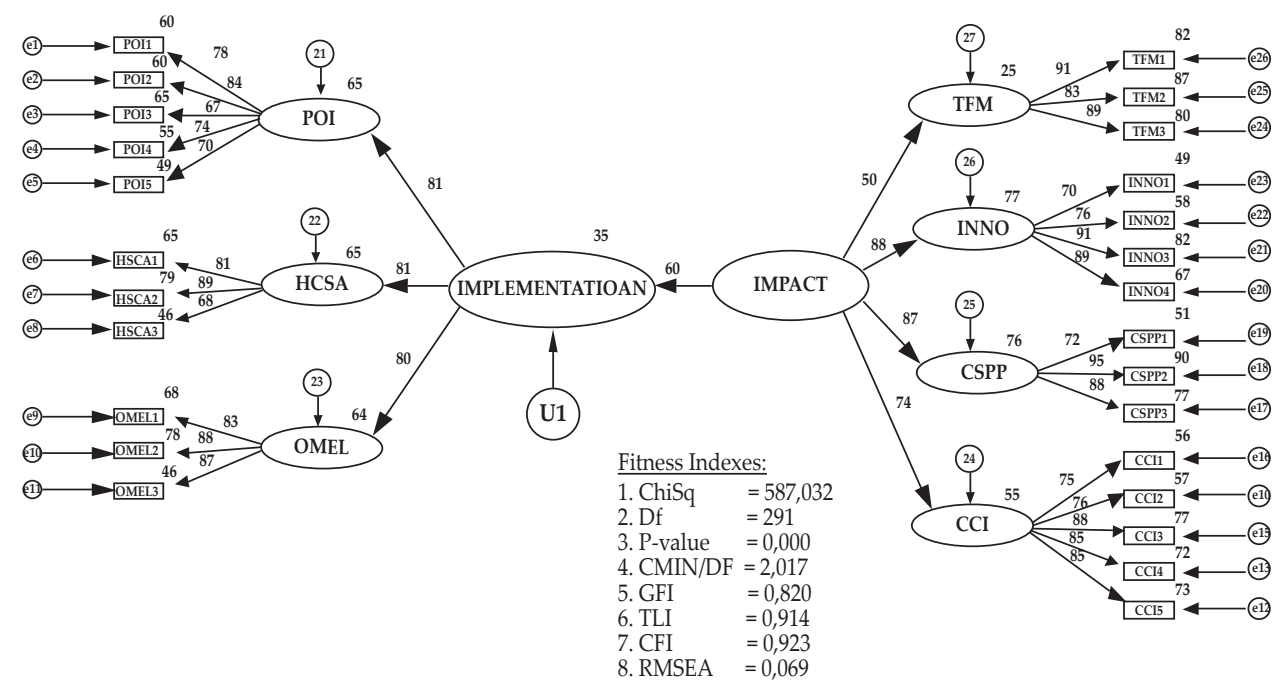

Figure 6.

Baseline Structural Model

After conducting the three-step analysis recommended by Byrne (2016), the final structural model was formed. In this analysis, there was no itemdeletion process based on the factor loading values, but only detection of model misspecification issues through modification indices (MI), standardised residual covariance, and examination of the goodness-of-fit (GOF). Therefore, the baseline structural model and the final structural model had the same number of variables: two MLVs, seven SLVs and 26 OVs.

As can be seen in Figure 7, all the fitness index values in this final structural model have been achieved, except for GFI, which is slightly below the cut-off value of 0.9 . Therefore, it can still be concluded that the construct validity for the model has been achieved and that the model fits the research data (observed variables) very well. In other words, this final structural model is ready for hypothesis testing. 


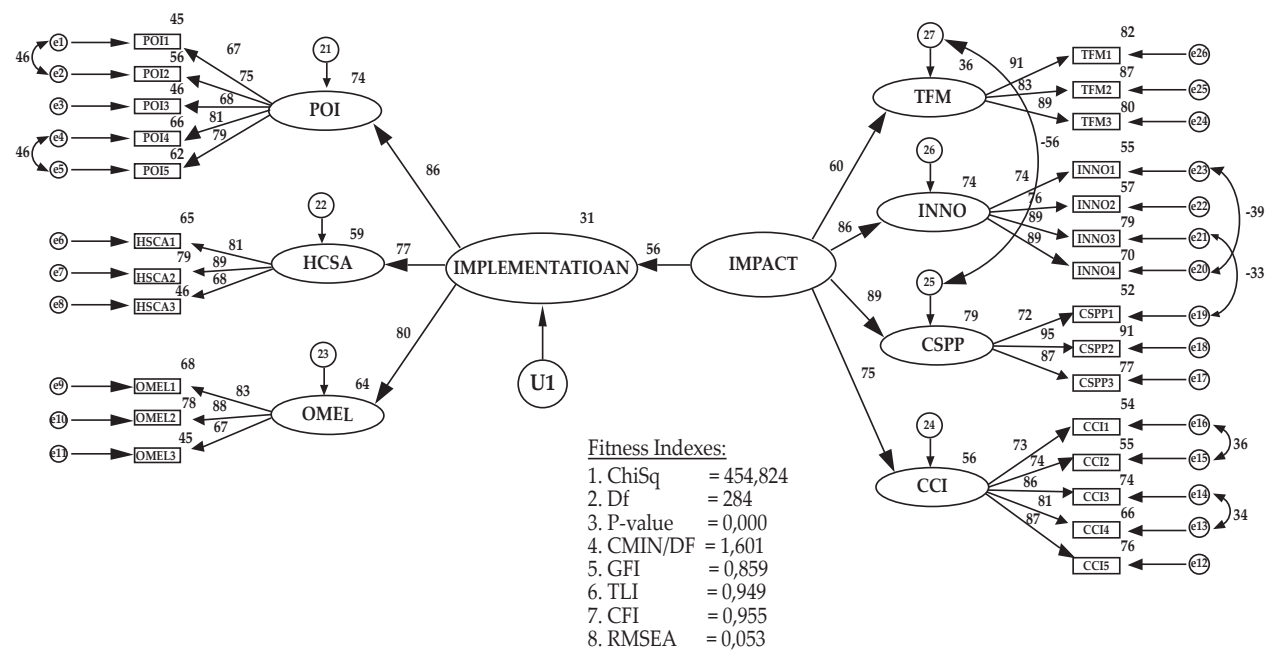

Figure 7.

Final Structural Model

\subsubsection{Hypothesis Testing}

Hypothesis testing was performed to examine the relationship between the implementation of MS1500 and its impacts. From Table 9, it can be seen that the structural path between implementation and impact is statistically significant, at $p<0.01$. This is because the value of $C R=5.789$ is greater than 2.58 (the value of the $\mathrm{t}$-table for $\mathrm{p}<0.01$ ). This indicates the positive relationship between implementation and impact at the $99 \%$ significance level.

In other words, it is shown that the implementation of MS1500 positively affects its impact. In practical terms, the better the implementation of MS1500 by the halal food industry in Malaysia, the greater the positive impact that it can achieve. In addition, it was also found that the value of SRW between implementation and impact was 0.558 , which means that every 1 unit increase in the quality of implementation leads to a 0.558 unit increase in the impact.

Table 9.

Structural Path Coefficients for Hypothesis Testing

\begin{tabular}{lcccccc}
\hline Structural Path & & & SRW & SE & CR & P \\
\hline POI & $<--$ & IMPLEMENTATION & 0.860 & 0.110 & 7.519 & $* * *$ \\
HCSA & $<--$ & IMPLEMENTATION & 0.768 & 0.132 & 8.075 & $* * *$ \\
OMEL & $<--$ & IMPLEMENTATION & 0.845 & 0.161 & 7.519 & $* * *$ \\
IMPLEMENTATION & $<--$ & IMPACT & 0.558 & 0.111 & 5.789 & $* * *$ \\
TFM & $<--$ & IMPACT & 0.604 & 0.151 & 6.590 & $* * *$ \\
INNO & $<--$ & IMPACT & 0.862 & 0.159 & 7.925 & $* * *$ \\
CSPP & $<--$ & IMPACT & 0.890 & 0.135 & 7.704 & $* * *$ \\
CCI & $<---$ & IMPACT & 0.751 & 0.153 & 6.590 & $* * *$ \\
\hline
\end{tabular}

Note: SRW = Standard Regression Weight; SE = Standard Error of Regression Weight; CR = Critical Ratio of Regression Weight; P = Level of Significance for Regression Weight. 
From Table 9, it can also be seen that the structural paths between POI, HCSA and OMEL in implementation, and between TFM, INNO, CSPP and CCI in impact are statistically significant at $\mathrm{p}<0.01$ as all of their $C R$ values are greater than 2.58. These values demonstrate that all the relationships in the final structural model are significant. It was also found that POI had the highest correlation with implementation and CSPP the highest with impact.

\subsection{Analysis}

The Malaysian government has high hopes that it will see flourishing accomplishments of MS1500. However, there have been many problems and challenges that have normally resulted in poor implementation of the MS. Accordingly, this holistic study of the implementation of MS1500 has been conducted.

Descriptive analysis of the company profiles found that the majority $(70.75 \%)$ preferred to renew their halal certificate every two years. This is because since 2014, JAKIM has requested that they pay for the first two-year period during their first application procedure. It was also found that most of the companies $(51.89 \%)$ had only implemented MS1500 for a fairly short period of time (1-3 years). This indicates that most of the respondent companies were newcomers in the halal food industry. Moreover, the results of descriptive analysis of the three main aspects of implementation are in line with the findings of Peter, Tran \& Adam (2013), who stated that "perception" and "core activity" were the most important aspects of implementation research.

The results of the EFA on the impact of the implementation of MS1500 show that each of the six types of impacts proposed by Bellina et al (2002) were only "formed factors". This indicates that these six type of impacts have been thoroughly investigated in previous studies. On the other hand, from the EFA on the implementation of MS1500, it was found that the three predefined factors in implementation became five formed factors. This might be because as yet there is no standardised theory of the implementation of halal standards. Additionally, the result of Cronbach's $\alpha$ test indicate that all the formed factors from EFA had good internal consistency.

From the CFA of MLV implementation, finance and regulation limitations (FRL) was removed because it has the lowest correlation with implementation. This finding contrasts with several previous studies, which have noted that financial constraints are the main limiting factor in food safety certification (Herath \& Henson, 2010; Macheka et al., 2013; Escanciano \& Santos-Vijande, 2014), especially for small-sized food companies due to their lack of financial resources (Abdul et al, 2008; Talib, Hamid, \& Chin, 2015). The finding also differs from previous studies, which have found that barriers imposed by certification regulatory bodies could lead to inefficient execution of the implementation of standards (Escanciano \& Santos-Vijande, 2014; and Talib, Hamid, \& Chin, 2015).

A reasonable explanation for these contradictory results is that most of the research respondents were halal executives $(25.94 \%)$ or owners $(23.58 \%)$, who represented their companies at halal exhibitions. Therefore, they believed that halal certification and halal food standards were important. In addition, finance 
and regulation are not major issues for such respondents. Most believe that such issues regarding halal food certification and standards can be overcome by the high commitment of owners, management, and employees. This belief of the respondents is in accordance with Talib, Hamid, \& Chin (2015), who state that high commitment from management and employees will facilitate the implementation of halal certification.

After the validity test, only three SLVs remained for the MLV implementation, namely POI, HCSA and OMEL. This is in accordance with the results obtained by Peter, Trans \& Adam (2013), which showed that each remaining sub-latent variable perfectly represents one of the three important aspects in implementation research. Precisely, POI represents the perception of the respondents about the context of implementation, HCSA represents the process of the implementation itself, and finally OMEL represents the limitations or barriers to implementation.

Furthermore, after conducting the validity test of MLV impact, it was found that only four SLVs remained: TFM, INNO, CSPP and consumer and corporate image (CCI). This result is different from the previously published theoretical models of Bellina et al. (2002), and may be due to the fact that the findings of this study relate specifically to halal food standards, whilst the theory of Bellina et al. (2002) is more generalised and for any type of standardisation. Aspects such as trade and free movement, and innovation and consumers are the same, but there is an apparent difference in the safety aspect. While the theory of Bellina et al. (2002) includes the 'impact of the safety and health of workers', this study found that the 'clean and safe production process' (CSPP) was one of sub-latent impact variables. This is because in Islam, Halal and Thoyib are entities that represent the symbol of intolerance in hygiene, cleanliness, safety and quality.

The results of the validity testing also show that consumer and corporate images are merged as one SLV under MLV impact. There are two reasons for this merger, the first being from a technical point of view (based on the findings of Tabachnick \& Fidell, 2007). Since consumer image only has two OVs, it was ineligible to be labelled as a factor or SLV. Therefore, it was merged to form one SLV, namely consumer and corporate image (CCI), with a total of five OVs. The second reason is that in theoretical terms, many previous studies have shown that there is a close relationship between consumer and corporate images (Esmeilpour \& Barjoei, 2016; Nguyen \& Leblanc, 2001).

After performing a series of data analyses, the study produced a final structural model with two MLVs, seven SLVs and $26 \mathrm{OVs}$, compared to the two MLVs, nine SLVs and $45 \mathrm{OVs}$ at the beginning. Based on this, a new questionnaire was developed for the main research framework with only 26 questions. This new questionnaire was much shorter and more compact in comparison to the original one.

From the hypothesis testing, it was found that the implementation of MS1500 did positively affect its impact. The better the implementation of MS1500 by the halal food industry in Malaysia, the greater the positive impact that they can achieve. This finding matches that of Peersman (2015), who argued that a wellchosen and well-implemented intervention should result in a good impact. In this study, the intervention is the implementation of MS1500.

It was also found that the perception of implementation (POI) was the most 
influential factor in the implementation of MS1500. This finding is in line with the work of Peters et al. (2013). The study also found that the clean and safe production process (CSPP) saw the biggest impact from the implementation of MS1500. This demonstrates that MS1500 is suitable for use as a halal food standard and emphasises the value of Halal and Thoyib.

The results of the study point to the positive impacts of the implementation of MS1500 and are expected to encourage all companies in the food industry in Malaysia to apply and fully implement the MS in their daily operations. The results are also expected to be useful for the Malaysian government or halal-related agencies, allowing them to find solutions to minimise the limitations and promote the MS globally. In addition, the new briefer and more compact questionnaire suggested by the established structural model is expected to be suitable as a data collection instrument in future studies on the implementation of halal food standard in Malaysia.

\section{CONCLUSION AND RECOMMENDATIONS}

\subsection{Conclusion}

The study has discovered that there is a close relationship between the implementation of MS1500 and its impacts, with a positive effect produced. The better the implementation of MS1500 by the halal food industry in Malaysia, the greater the positive impact it can achieve. The biggest impact that can be achieved by industries that implement MS1500 relates to the clean and safe production process (CSPP), followed by impacts on innovation, consumers and corporate image, and trade and free movement.

Moreover, it was found that finance and regulation were not factors that resulted in limitations to the implementation of MS1500, a finding which is in contrast with several previous studies. The reason for the difference is likely to be due to the fact that the majority of the respondents were participants in food or halal exhibitions. Consequently, their opinions could be biased as they were all fully aware of and eager to implement MS1500.

\subsection{Recommendations}

The recommendations of the study are divided into three categories. First, for future studies, an expanded sample size is recommended, as well as a concerted effort to conduct a holistic and sequential study which not only focuses on conditions after implementation, but also before it. It is also recommended that quantitative and qualitative methods are combined. Therefore, after obtaining the quantitative data from the distributed questionnaire, a focus group discussion (FGD) attended by a minimum of one respondent or representative from each company should be held.

Second, it is suggested that the halal food industry in Malaysia has its own internal halal control system, with its own halal committee. All halal food companies should also improve their employees' skills and knowledge about food safety and halal food standards.

Finally, the Malaysian government or halal regulatory agencies are expected to increase the promotion of MS1500 locally and internationally. Furthermore, 
to attract more halal certificate applicants and develop the implementation of MS1500, JAKIM should ease and simplify the certification process. Guidance and monitoring processes during the implementation of MS 1500 need to be boosted, especially for newcomers to the industry.

\section{REFERENCES}

Abdul, M., Ismail, H., Hashim, H., \& Johari, J. (2008). SMEs and halal certification. In: N. K. Nik Muhamad, Y. H. Bidin, W. H. Wan Hasan, A. Ariffin, M. Idrus, ... \& W. N. Wan Mohamed (Eds), Proceedings of ECER Regional Conference: Thrusting Islam, Knowledge and Professionalism in ECER Development. Paper presented at the ECER Regional Conference, Kota Bharu, Kelantan, Malaysia. (pp. 609-618). UiTM: UPENA.

Ahmad, H. Wahid, \& Kastin, S. (2007). PKS di persada dunia melalui tanda halal: Kes gelagat pengguna [SMEs on the world stage through halal marks: A case of consumer behavior]. Penjenamaan Halal: Satu Paradigma Baru (in Malay), (Ed), 71-97.

Asa, R. S. (2017). Malaysian halal certification: Its religious significance and economic value. Shariah Journal, 25(1), 137-156.

Atikah, N. (2016). consumer perception towards halal logo and certification: A study among the students of faculty syariah and law, Islamic Science University of Malaysia (Bachelor Thesis). Faculty of Syariah and Law, Universiti Sains Islam Malaysia. Nilai, Malaysia.

Aziz, Y. A. \& Chok, N. V. (2013). The role of halal awareness, halal certification and marketing components in determining halal purchase intention among non-muslim in malaysia: A structural equation modelling approach. Journal of International Food and Agribusiness Marketing, 25(1), 1-23.

Batu, A., \& Regenstein, J. M. (2014). Halal food certification challenges and their implications for muslim societies worldwide. Turkish Studies - International Periodical for the Languages, Literature and History of Turkish or Turkic, 9(11), 111130.

Bellina, N., Bullock, C., Duffy, P., Ferrero, M. L., Faughnan, L., ... \& Paterson, E. (2002). Study into the Impact of Standardization: Final Report to DG Enterprise. Impacts of Standards Users Group.

Bentler, P. M. \& Chou, C. P. (1987). Practical issues in structural modelling. Sociological Methods and Research, 16(1), 78-117.

Blind, K. (2004). The Economics of standards: Theory, evidence, policy. Cheltenham: Edward Elgar Publishing.

Blind, K. (2013). The Impact of standardization and standards on innovation: Compendium of evidence on the effectiveness of innovation policy intervention. manchester institute of innovation research. Manchester Business School, University of Manchester, UK.

Bohari, A. M., Hin, C. W., \& Fuad, N. (2013). The Competitiveness of halal food industry in Malaysia: A SWOT - ICT analysis. Malaysia Journal of Society and Space, 9(1), 1-9.

Brown, A. N. (2016). Differences between the theory of change and the logic model. Retrieved from https://www.annmurraybrown.com/single-post/2016/03/20/ theory-of-change-vsthe-logic-model-never-be-confused-again. 
Burnham, K. P. \& D. R. Anderson (2013). Model selection and inference: A practical information-theoretic approach. New York: Springer.

Byrne, B.M. (2016). Structural equation modelling with AMOS: Basic concepts, applications, and programming. (3rd New Edition). New York: Taylor \& Francis Ltd.

Cheung, M. W. L. (2015). Meta-analysis: A structural equation modelling approach. Chichester: Wiley.

Cheung, G. W. \& R. S. Lau (2008). Testing mediation and suppression effects of latent variables: Bootstrapping with structural equation models. Organisational Research Methods, 11(2), 296-325.

Dankers, C. (2003). Environmental and social standards, certification and labelling for cash crops. FAO. http://www.fao.org/docrep/006/y5136e/ y5136e00.htm.

Department of Standards Malaysia (SIRIM). (2009). Malaysian standard MS1500: 2009 halal food-production, preparation, handling and storage-general guidelines (2nd Revision).

Din, R. C. \& Daud, S. (2014). Critical success factors of MS1500:2009 implementation. Proceeding-Social and Behavioural Sciences, 121(19 March 2014), 96-103.

Dunn, M., Glasgow, R., Handley, K., Kayondo, J. K., Kupfer, L., ... \& Werder, E. (2012). Fundamentals of Implementation Research. Measure Evaluation. U.S: Agency for International Development.

Escanciano, C., \& Santos-Vijande, M. L. (2014). Implementation of ISO-22000 in Spain: Obstacles and key benefits. British Food Journal, 116(10), 1581-1599.

Esmeilpour, M., \& Barjoei, S. (2016). The Effect of corporate image on customer satisfaction through brand equity. Journal of Advances in Management $\mathcal{E}$ Applied Economics, 6(4), 95-109.

Fixsen, D. L., Naoom, S. F., Blase, K. A., Friedman, R. M., \& Wallace, F. (2005). Implementation research: A synthesis of literature. National Implementation Research Network. The Pennsylvania State University.

Giovannucci, D., \& Reardon, T. (2001). Understanding grades and standards and how to apply them. A guide to developing agricultural markets and agro-enterprises. The World Bank

Grewal, R., Cote, J. A., \& Baumgartner, H. (2004). Multicollinearity and measurement error in structural equation models: Implications for theory testing. Marketing Science, 23(4), 519- 529.

Hair, J. F., Black, W. C., Babin, B. J., \& Anderson, R. E. (2010). Multivariate data analysis: A global perspective. (7th Edition). Upper Saddle River, New Jersey: Pearson Education.

Hair, J. F. J., Hult, G. T. M., Ringle, C. M. \& Sarstedt, M. (2014), A primer on partial least squares structural equation modelling (PLS-SEM). Thousand Oaks, CA: Sage.

Hawkins, R., Blind, K., \& Page, R. (2017). Handbook of innovation and standard. Cheltenham, UK: Edward Elgar Publishing Limited.

Herath, D., \& Henson, S. (2010). Barriers to HACCP implementation: Evidence from the food processing sector in Ontario, Canada. Agribusiness, 26(2), 265279.

Hoyle, R. H., \& Smith, G. T. (1994). Formulating clinical research hypotheses as structural equation models: a conceptual overview. Journal of Consulting and Clinical Psychology, 62(3), 429-440. 
International Standard Organization (ISO) (2004). ISO/IEC GUIDE 2:2004. Standardization and related activities - General vocabulary.

Jais, A. S. (2019). Halal related Malaysian standards. Halal Note Series-Halal Common, 1.

Jungmittag, A., Blind, K., \& Mangelsdorf, A. (2011). The Economic Benefits of Standardization. DIN, Germany.

Kaur, M. (2016, September 1). Minister Suggest Easier Halal Certification for Muslim Firms. Free Malaysia Today. http://www.freemalaysiatoday.com/category/ nation/2016/09/01/minister-suggests-easier-halal-certification-for-muslimfirms/.

Kline, R. B. (2011). Principles and practice of structural equation modelling. (3rd Ed). New York: The Guilford Press.

Kock, N., \& Lynn, G. S. (2012). Lateral collinearity and misleading results in variance-based SEM: An illustration and recommendations. Journal of the Association for Information System, 13(7), 546-580.

Latief, I. A., Mohamed, Z., Sharifuddin, J., Abdullah, A. M. \& Ismail, M. M. (2014). A comparative analysis of global halal certification requirements. Journal of Food Products Marketing, 20(sup1), 85-101.

Macheka, L., Manditsera, F. A., Ngadze, R. T., Mubaiwa, J. \& Nyanga, L. K. (2013). Barriers, benefits and motivation factors for the implementation of food safety management 28 system in the food sector in Harare province, Zimbabwe. Food Control, 34(1), 126-131.

Malaysia International Trade and Industry. (2014). MITI Annual Report. https:// www.miti.gov.my/miti/resources/MITI_Report_20141.pdf

Manders, B. (2015). Implementation and Impact of ISO 9001. Doctorate Thesis. Erasmus Research Institute of Management (ERIM). Erasmus University Rotterdam, Netherland.

Ministry of International Trade and Industry Malaysia. (2017). MITI Weekly Bulletin, 441.

Ministry of Economic Affair \& Halal Development Corporation. (2020). Halal Industry Master Plan 2030. Executive Summary.

Mitchell, R. J. (1992). Testing evolutionary and ecological hypotheses using path analysis and structural equation modelling. Functional Ecology, 6(2), 123- 129.

Mohamed, Z. A., Shamsudin, M. N., \& Rezai, G. (2013). The effect of possessing information about halal logo on consumer confidence in Malaysia. Journal of International Food and Agribusiness Marketing, 25(sup1), 73-86.

Nawi, N. M. \& Nasir, N. I. M. (2014). Consumers' attitude toward the food safety certificate (FSC) in Malaysia. Journal of Food Products Marketing, 20(sup1), 140150.

Nguyen, N., \& Leblanc, G. (2001). Corporate image and corporate reputation in customers' retention decisions in services. Journal of Retailing and Consumer Services, 8(4), 227-236.

Nunnally, J. C. (1978). Psychometric theory (2nd ed). New York: McGraw-Hill.

Padian, N. S., C.B. Holmes, S.I. McCoy, R. Lyerla., Bouey, P. D., \& Goosby, E. P. (2011). Implementation science for the US president's emergency plan for AIDS relief (PEPFAR). Journal of Acquired Immune Deficiency Syndromes, 56(3), 199-203. 
Peersman, G. (2015). Impact evaluation. Better Evaluation. Retrieved from http:// www.betterevaluation.org/themes/impact_evaluation.

Peters, D. H., Tran, N. T., \& Adam, T. (2013). Implementation research in health: A practical guide. World Health Organization.

Pickering, L. (2015). The truth about halal certification: Part 1 of 12 Parts Series. Pickering Post. http://www.pickeringpost.com/story/the-truth-about-halalcertification/4559.

Prates, G. A., \& Caraschi, J. C. (2014). Organizational impacts due to ISO 9001 certified implementation on Brazilians cardboard companies. International Journal of Academic Research in Business and Social Sciences, 4(5), 501-502.

Preedy, V. R., \& Watson, R. R. (2009). Handbook of disease burdens and quality of life measures. New York: Springer.

Rafiki, A. (2019). Impact, perception and challenges due to halal certification: The case of zulaikha shop. In E. M. Ghazali, D. S. Mutum, M. Rashid, \& J. U. Ahmed (Eds.), Management of Shari'ah Compliant Businesses (pp. 139-153).

Shafie, S. \& Othman, M. N. (2006). Halal Certification: An International Marketing Issues and Challenges. CTW Congress. http://www.ctwcongress.de/ifsam/ download/track_13/pap0 0226.pdf.

State of the Global Islamic Economy (SGIE) (2019). Driving the Islamic Economy Revolution 4.0. The 7th Annual State of the Global Islamic Economy Report (2019/2020).

Sunarya, Firdausy, C. M., Busneti, I., \& Adinugroho, T. P. (2015). Manfaat ekonomi standar [Standard economic benefits]. Jakarta: Badan Standardisasi Nasional.

Tabachnick, B. G., \& Fidell, L. S. (2012). Using multivariate statistics (6th Ed). London: Pearson Education.

Talib, H. A., \& Ali, K. A. M. (2009). An overview of Malaysian food industry: The opportunity and quality aspects. Pakistan Journal of Nutrition, 8(5), 507-517.

Talib, M. S. A, Hamid, A. B. A., \& Chin, T. A. (2015). Motivation and limitation in implementing halal certification: A pareto analysis. British Food Journal, 117(11), 2664-2705. DOI: 10.1108/BFJ-02-2015-005.

Talib, M. S. A., Sawari, S. S. M., Hamid, A. B. A., \& Chin, T. A. (2016). Emerging halal food market: An institutional theory of halal certificate implementation. Management Research Review, 39(9), 987-997. http://doi.org. 10.1108/MRR-062015-0147.

Tsiotras, G., \& Gotzamani, K. (1996). ISO 9000 as an entry key to TQM: The case of greek industry. The International Journal of Quality \& Reliability Management, 13(4), 64-76.

Verlag, B. (2000). Economic Benefit of Standardization. DIN German Institute for Standardization.

Weitzel, T., Beimborn, D., \& Konig, W. (2006). A unified economic model of standard diffusion: The impact of standardization cost, network effects and network topology. MIS Quarterly, 30(Special Issue), 489-514.

Weston, R., \& Gore, P. A., Jr. (2006). A brief guide to structural equation modelling. The Counselling Psychologist, 34(5), 719-751.

World Bank (2004). Monitoring \& Evaluation: Some Tools, Methods \& Approaches. World Bank Operation Evaluation Department. 
http://documents.worldbank.org/curated/en/829171468180901329/ pdf/246140UPDATED01s1methods1approaches.pdf.

World Health Organisation (2014). Implementation Research Toolkit: Facilitator's Guide. Training in Tropical Disease of Poverty. WHO Library.

Zhang, M. F, Dawson, J. F., \& Kline, R. B. (2020). Evaluating the use of covariancebased structural equation modelling with reflective measurement in organizational and management research: A review and recommendations for best practice. British Journal of Management, 32(2), 257-272. 